\title{
Passage performance of long-distance upstream migrants at a large dam on the Paraná River and the compounding effects of entry and ascent
}

\author{
Ricardo Luiz Wagner ${ }^{1}$, Sergio Makrakis², Theodore Castro-Santos ${ }^{3}$, Maristela \\ Cavicchioli Makrakis², João Henrique Pinheiro Dias ${ }^{4}$ and René Fuster Belmont ${ }^{4}$
}

\begin{abstract}
This paper presents results of a fishway evaluation performed at the Engenheiro Sérgio Motta Hydroelectric Power Plant (known as Porto Primavera) - CESP, Paraná River, Brazil. The evaluation was designed to quantify entry and passage proportions of 4 long-distance migratory fish species: Brycon orbignyanus (piracanjuba), Piaractus mesopotamicus (pacu), Prochilodus lineatus (curimba), and Rhinelepis aspera (cascudo-preto). Proportions finding and entering the fishway differed between species, ranged from $7.4 \%$ (Prochilodus lineatus) to 55.4\% (Piaractus mesopotamicus). Also, proportion passing was different between species, ranged from $31 \%$ (R. aspera) to $100 \%$ (Prochilodus lineatus). Fish that were marked and released within the fishway had greater failure rates than those that entered volitionally. Total time to pass ranged from 1.48 hours (Prochilodus lineatus) to 178.9 hours (R. aspera). Failure rates were greatest in the lower end of the fishway. Although some individuals of all species passed successfully, significant challenges remain to restoring connectivity of the upper Paraná River.
\end{abstract}

Este artigo apresenta resultados da avaliação de passagem de peixes na escada localizada na Usina Hidrelétrica Engenheiro Sérgio Motta - CESP (rio Paraná, Porto Primavera, Brasil). A avaliação foi concebida para quantificar a entrada e proporções de passagem de quatro espécies de peixes migradores de longa distância: Brycon orbignyanus (piracanjuba), Piaractus mesopotamicus (pacu), Prochilodus lineatus (curimba) e Rhinelepis aspera (cascudo-preto). As proporções de encontrar e entrar na escada variaram de 7,4\% (Prochilodus lineatus) para 55,4\% (Piaractus mesopotamicus). A proporção de passagem através da escada variou de $31 \%$ (R. aspera) a 100\% (Prochilodus lineatus). Os peixes que foram marcados e soltos no interior da escada apresentaram taxas maiores de falha do que aqueles que entraram voluntariamente. O tempo médio para passar variou de 1,48 horas (Prochilodus lineatus) para 178,9 horas (R. aspera). A taxa de falha foi maior no extremo inferior da passagem para peixes. Embora alguns indivíduos de todas as espécies passaram com sucesso, desafios significantes permanecem para restaurar a conectividade do alto rio Paraná.

Key words: Attraction, Dams, Fish ladder, Fishway, Migration, Swimming performance.

\section{Introduction}

Most of the migratory fish of the Paraná River spawn in the upper sections of large tributaries, where lagoons along the margins provide essential nursery habitat (Agostinho et al., 2003; Agostinho et al., 2004a). Upstream migrating adults are prevented from accessing spawning habitat by dams and reservoirs (Makrakis et al., 2011). River regulation affects juveniles and downstream migrants as well: by reducing frequency and magnitude of floods, larvae are not conveyed to floodplains, and important nursery habitat is eliminated. This has led to a general decline in populations of migratory fish, with fragmented populations concentrating between dams with little exchange among populations (Agostinho et al., 2004b; Agostinho et al., 2008).

Fishways at dams, such as ladders, sluices, semi natural channels and lifts (Clay, 1995), are implemented to mitigate these effects, and re-establish connectivity between habitats

\footnotetext{
${ }^{1}$ Universidade Estadual do Oeste do Paraná, Programa de Pós-Graduação em Recursos Pesqueiros e Engenharia de Pesca. Rua da Faculdade, 645, Jardim Santa Maria. 85903-000 Toledo, Paraná, Brazil. ricabatata@hotmail.com

${ }^{2}$ Universidade Estadual do Oeste do Paraná, Grupo de Pesquisa em Tecnologia de Produção e Conservação de Recursos Pesqueiros e Hídricos (GETECH), Programa de Pós-Graduação em Recursos Pesqueiros e Engenharia de Pesca. Rua da Faculdade, 645, Jardim Santa Maria.85903-000 Toledo, Paraná, Brazil.makrakis@terra.com.br (SM); mmakrakis@terra.com.br (MCM)

${ }^{3}$ Silvio O. Conte Anadromous Fish Research Center, U. S. Geological Survey, Leetown Science Center, One Migratory Way, P.O. Box 796, Turners Falls MA 01376 U.S.A. TCastro_Santos@usgs.gov

${ }^{4}$ Companhia Energética de São Paulo (CESP). Rodovia Marechal Rondon, km 667. 16920-000 Castilho, São Paulo, Brasil. joao.dias@cesp.com.br(JHPD); rene.belmont@cesp.gov.br (RFB)
} 
(Godoy, 1985; Prosser, 1986; Quirós, 1988). In some cases, alterations and losses of upstream habitats may be so severe that connectivity is no longer desirable, particularly where viable habitat still exists downstream (Pelicice \& Agostinho, 2008). Where populations are fragmented, however, it may still be useful to pass a portion of the population, if the purpose is only to maintain genetic diversity of the upstream population. The effectiveness of fishways, either in restoring connectivity, bypassing viable habitat, or maintaining genetic diversity, can only be understood by documenting their effectiveness. Although there are several fishways in South America rivers, few of them have been monitored or evaluated. The few studies evaluating fish passages have indicated problems related to their functioning (Pompeu et al., 2012), and most of them concentrated mainly on the selectivity of fish ladders on ascending fish.

The efficiency of a fish passage has been considered predominantly as a qualitative concept, which involves checking whether the system provides satisfactory passage for the target-species, under the environmental conditions observed during the migratory period (Makrakis et al., 2011). Quantitative assessments of efficiency take into account the percentage of fish present in one side of the passage that are able to move through it (Larinier, 2001, 2002; Castro-Santos et al., 2009). In order to pass a fishway, however, fish must first enter it, and percent entry and percent passage can be thought of as independent processes that drive overall passage success (Bunt et al., 1999; Bunt et al., 2012). Percent entry itself comprises two discrete steps: fish must first locate the entrance (guidance), and once within the attraction zone of the fishway they must choose to enter. Each of these three steps: guidance, entry, and passage, can be quantified as rates (proportion $x$ time $^{-1}$ ), and the success of any fishway depends on these three rates acting together, and a comprehensive understanding of fish passage requires that all three rates be quantified (Collins \& Elling, 1960; CastroSantos \& Haro, 2010). Sometimes it is not possible to separately quantify all three components - in this case researchers must recognize the limitations of their study and interpret their data accordingly (Bunt et al., 2012).

RFID (radio frequency identification) systems have been widely used for monitoring fish movements. Development of small and inexpensive passive integrated transponder (PIT) tags has allowed researchers to tag large numbers of individuals with unique codes and monitor movements (Prentice et al., 1990; Castro-Santos et al., 1996; Armstrong et al., 1996; Greenberg \& Giller, 2000). Because PIT tags do not require batteries (they receive their transmission energy from the detection antenna) they have an almost unlimited life expectancy (Castro-Santos et al., 1996), and so are useful for long-term studies. This technique has the great advantage of enabling data collection without recapturing the animal, thus avoiding the stress caused by handling (Prentice et al., 1990). This is particularly important when studying passage performance at fishways, and PIT telemetry has been shown to be an effective method for quantifying passage without handling individuals (Castro-Santos et al., 1996).

This study documents the effectiveness of a fish ladder for Neotropical long-distance migratory species using PIT telemetry. Specifically, we wanted to answer the following questions: i) What proportion of the target populations enter the ladder, and are these proportions the same among species? ii) Are there differences in passage rate among the studied species? iii) How long does it take for fish to pass the structure?

\section{Material and Methods}

\section{Study area}

The Engenheiro Sérgio Motta Hydroelectric Power Plant, known as Porto Primavera, belongs to the Companhia Energética de São Paulo (CESP). It can generate $1800 \mathrm{MW}$ of hydroelectricity and has a 220,000-ha reservoir. The dam is 13 $\mathrm{km}$ wide, $22 \mathrm{~m}$ high, and it is located in the main channel of the Paraná River, along the border between São Paulo and Mato Grosso do Sul, Brazil (Fig. 1).

A fish ladder (weir and orifice type) was built on the left side of the dam, allowing fish to reach the reservoir (Makrakis et al., 2007a). The ladder ends immediately below the powerhouse. The ladder is $520 \mathrm{~m}$ long and its upper end is next to the reservoir at an elevation of $255.5 \mathrm{~m}$ (entrance of water), while the lower end is at an elevation of $235.5 \mathrm{~m}$, entering into the Paraná River at an angle of $45^{\circ}$. Fifty concrete weirs form the pools, and each pool is $5 \mathrm{~m}$ wide $\mathrm{x} 2 \mathrm{~m}$ high. These weirs are $8 \mathrm{~m}$ apart from each other, and each one has six orifices (three at the upper side and three at lower side). The water intake of the ladder is regulated by a fixed opening; flow varies from 3.0 to $3.5 \mathrm{~m}^{3} / \mathrm{s}$ and is determined by the water level.

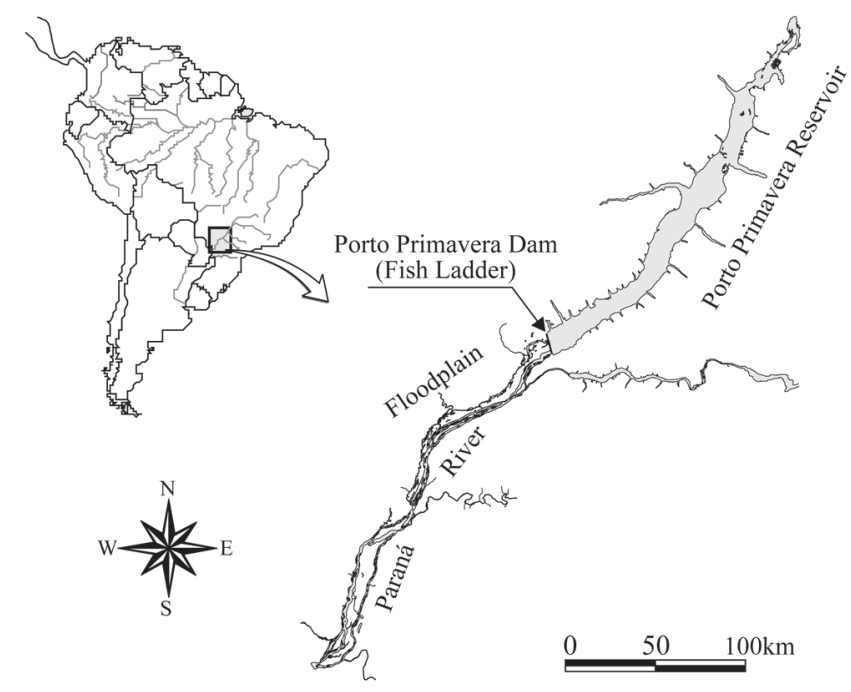

Fig. 1. Location of Engenheiro Sérgio Motta (Porto Primavera) Hydroeletric Power Plant, Paraná River, Mato Grosso do Sul, São Paulo States, Brazil. 


\section{Data sampling}

After performing tests for the choice of sites and configuring the RFID system, eight antennas measuring $1.5 \mathrm{x}$ $3.0 \mathrm{~m}$ were installed inside the fish ladder. Antennas comprised loops of insulated stranded copper wire $\left(4 \mathrm{~mm}^{2}\right)$, threaded through frames made of PVC pipe. These frames were fixed to blocks of wood attached to the concrete structure of the ladder. The first antenna (antenna 1) was installed $100 \mathrm{~m}$ upstream from the fishway entrance, just above the first resting pool. Although this was well upstream of the actual fishway entrance, potential for high flows precluded placing this antenna any closer. For the purposes of this study, therefore, we consider this first antenna to represent the fishway entrance, but readers should be aware that significant failure may have occurred downstream of the first antenna. The last (antenna 8) was positioned at the upstream end of the fishway, $50 \mathrm{~m}$ downstream of the fishway exit (Fig 2; Fig. 3a). The other antennas were distributed between the first and the last antenna in the fish ladder. The slope through the fish ladder and distances between antennas are showed in Table 1.
Two RFID reader systems (TIRIS Series 2000 - Texas Instruments, Austin, TX, USA) were used to monitor the fishway. Each system comprised 4 units interfaced with a computer running custom software that logged detections at each antenna in real-time to the nearest 0.01 s (USGS 2002) (Fig. 3b). The RFID system ran continuously from the beginning of fish marking and release on $13^{\text {th }}$ November 2009 , until $13^{\text {th }}$ April 2010.

Individuals of four long-distance migratory species were marked: Brycon orbignyanus (Valenciennes, 1850) (locally known as 'piracanjuba'), Piaractus mesopotamicus (Holmberg, 1887) (locally known as 'pacu'), Prochilodus lineatus (Valenciennes, 1837) (locally known as 'curimba'), and Rhinelepis aspera Spix \& Agassiz, 1829 (locally known as 'cascudo-preto'). Individuals of the species B. orbignyanus and Piaractus mesopotamicus came from Estação de Hidrobiologia e Aqüicultura de Jupiá - CESP (a hatchery of wild fish caught in Paraná River basin), whereas the species Prochilodus lineatus and $R$. aspera were captured within the fish ladder using trawls and cast nets. Fish were tagged and

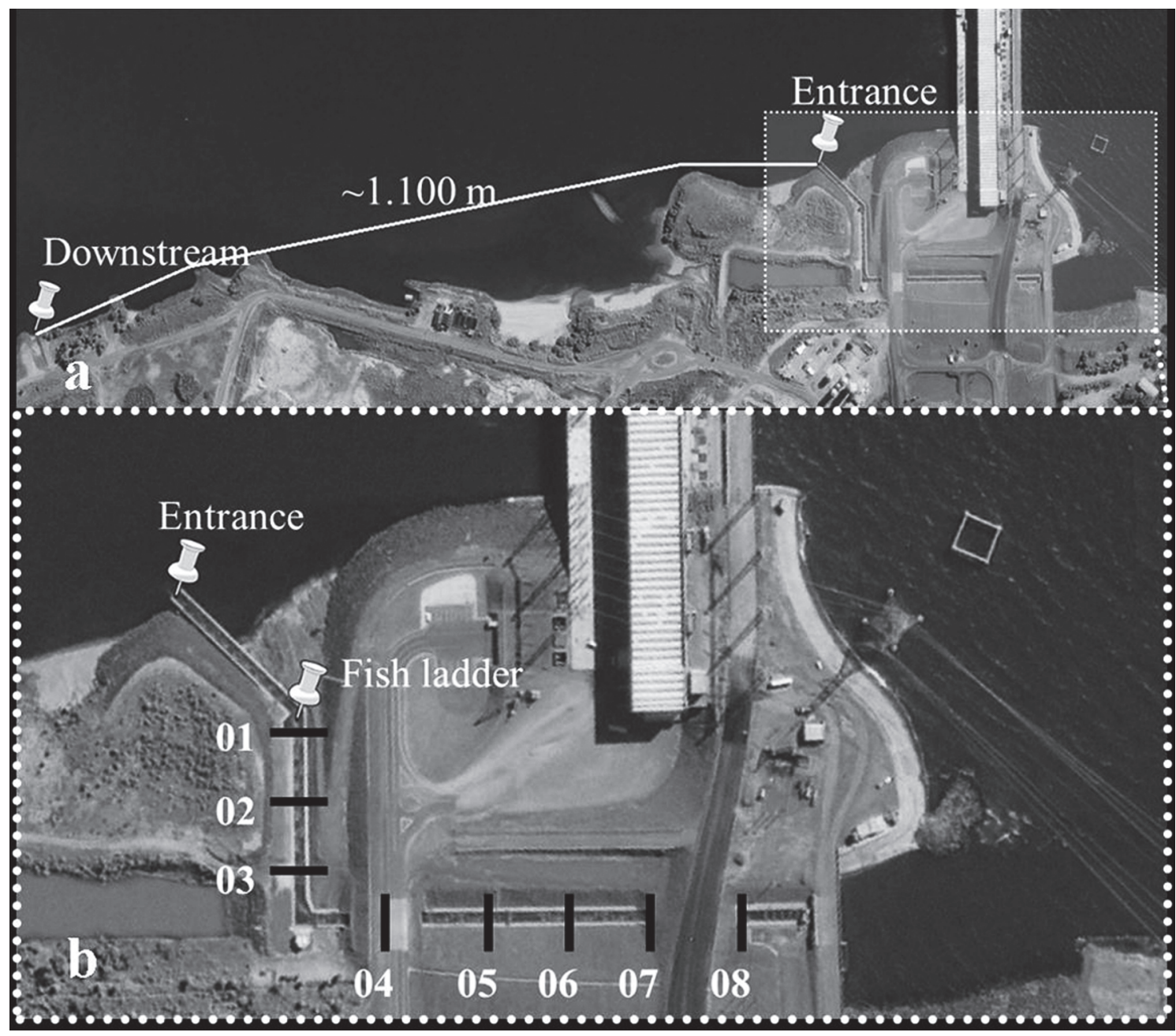

Fig. 2. Fish release sites: a) downstream, and b) fish ladder - distribution of antennas (01 to 08) along the fish ladder at the Engenheiro Sérgio Motta (Porto Primavera) Hydroeletric Power Plant. 
Table 1. Distance (m) and slope (\%) among antennas along fish ladder of Porto Primavera.

\begin{tabular}{ccc}
\hline Antennas & Distance $(\mathrm{m})$ & Slope $(\%)$ \\
\hline $1-2$ & 50.11 & 5.05 \\
$2-3$ & 27.23 & 5.05 \\
$3-4$ & 70.45 & 5.12 \\
$4-5$ & 46.32 & 4.34 \\
$5-6$ & 46.81 & 4.99 \\
$6-7$ & 42.43 & 4.02 \\
$7-8$ & 39.08 & 4.99 \\
\hline
\end{tabular}

released over a period of four months (November 2009 February 2010). Before tagging, fish were anesthetized with benzocaine $75 \mathrm{mg} / \mathrm{l}$, diluted in ethyl alcohol $\left(92.8^{\circ}\right)$. Tags (32 $\mathrm{mm}$ PIT tags, TIRIS model RI-TRP-WR2B 30) were then surgically implanted (IP) (Fig. 3c-d).

After tagging, fish were transported in transport boxes (volume of 1000 l) with oxygenation to one of the two release sites: the first site ('Downstream') was located $1.100 \mathrm{~m}$ downstream of the fish ladder, on the left bank - this is the same bank as the fishway is located; the second release site was within the fishway itself, $85 \mathrm{~m}$ from the entrance (Fig. 2). Fish were placed in a cage adjacent to the release site (Fig. 3e) and held for 20 minutes before being released.

\section{Data analysis Entry rate}

To evaluate the ability of fish to find and enter the ladder, we quantified the proportion and timing of marked individuals released downstream that found the entrance of the ladder (as represented by detection at the first antenna). The time elapsed between the moment of release and the moment of passing through antenna 1 was measured, and estimates of cumulative distribution functions for the time elapsed were calculated using the Kaplan-Meier method (Kaplan \& Meier, 1958; Allison, 1995; Castro-Santos \& Haro, 2003). This method derives from survival analysis techniques, and allows for quantification of event rates, and explicitly includes those animals that fail to enter as censored observations (CastroSantos \& Haro, 2003). Because no follow-up was possible, we assumed $100 \%$ survival, and assigned censoring times equal to the longest entry time for those individuals that failed to enter. The assumption of $100 \%$ survival is consistent with tagging and survival studies performed using similar methods (Zydlewski et al., 2001; Sullivan, 2004).

\section{Passage efficiency}

We also used survival analysis to quantify ascent up the fishway (Allison, 1995; Haro et al., 2004). Survival analysis used to assess fish passage systems, through survivorship (S(D)) and hazard functions (h(D)), can help detect possible parts of the ladder that hinder the passage or even impede fish ascension (Castro-Santos, 2004; Haro et al., 2004; Makrakis et al., 2011; Thiem et al., 2011). For this analysis, we used distance of ascent as the response variable (event) indicated by detection at antennas 1-8 (Haro et al., 2004;
Makrakis et al., 2011). The survivorship function (S (D)) is the complement of the cumulative distribution function (CDF) - sometimes called a 'depletion curve', it begins at 1 and declines in proportion to the proportion failing at each location. In the case of a fishway, where censoring only occurs at the top, the final value of the survival curve is equal to the overall proportion passing. The hazard function (h (D)) can be derived from $S(D)$, and is the instantaneous proportion of the available population failing per unit time (or in this case distance). For any given location, fish that had already failed were not included in the denominator, producing a least-biased estimator of failure rate at each location (SAS, 2009). Transit time between antennas and cumulative transit time required traveling from antenna 1 to 8 were measured.

Although distance of ascent is an intuitive measure of passage performance, it may be more appropriate to think of passage success or failure as being the outcome of two distinct and competing processes: time to pass, and time to fail (Castro-Santos, 2012; Castro-Santos \& Perry, 2012). We estimated these two rates by recording the first and last observations within the fishway. Those that passed were censored with respect to failure time and complete with respect to passage time, and those that failed were complete with respect to failure time and censored with respect to passage time. Comparing passage and failure rates complements the hazard analysis described above, and can help explain sources of failure and success.

To test the difference between the fish species checking the proportion passing and transit time, as well as time to fail and time to pass for fish species between release sites (downstream and fish ladder), we used the survivorship curves by applying the PROC LIFETEST (SAS 9.3, 2010) and analysed the log-rank and Wilcoxon statistics for each treatment group, followed by an estimate of their covariance matrix. The tests readily generalize to two groups, with the null hypothesis that all groups have the same survivor function. If the null hypothesis is true, the test statistics all have chi-square distributions with degrees of freedom equal to the number of groups minus 1 . The univariate procedure was applied to test for normality of data using SAS 9.3.

\section{Results}

We marked and released 757 fish at the downstream site: 151 B. orbignyanus, 204 Piaractus mesopotamicus, 196 Prochilodus lineatus, and 206 R. aspera. The proportion entering the fishway varied among species, with greatest entry rate was by Piaractus mesopotamicus (55.4\%), followed by R. aspera (25.7\%), B. orbignyanus (15.9\%), and Prochilodus lineatus $(7.1 \%)$.

The species marked and released downstream differed in time elapsed (days) to find the ladder. The chi-square tests of the null hypothesis that the survivor functions are identical across the four strata were significant at the 0.05 level. Both the log-rank and Wilcoxon tests comparing the species were 


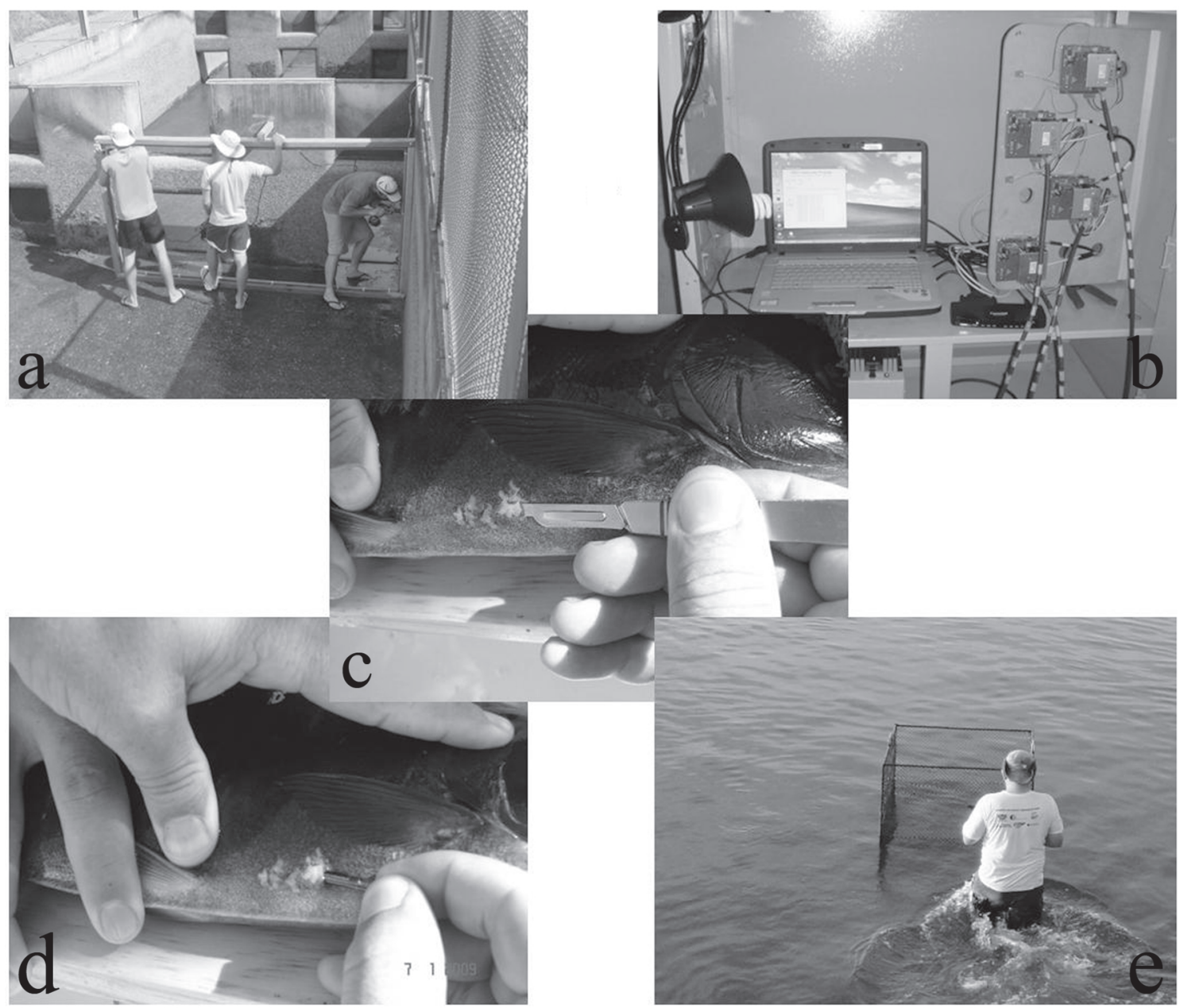

Fig. 3. Details of methodology: a) installation of antenna, b) RFID system, $\mathbf{c}$ and $\mathbf{d}$ ) marking of fish, e) cages for fish.

significant (Log-Rank, $\mathrm{p}<0.0001$; Wilcoxon, $\mathrm{p}<0.0001$ ). Rhinelepis aspera was detected by the first antenna in shorter time and higher quantity, in up to 20 days after release, with an average of $10 \pm 11$ days. It is intriguing that the majority of individuals of other species found entrance of fish ladder concentrated around 80-90 days (Fig. 4).

In the fish ladder, we marked and released 317 individuals: 100 Piaractus mesopotamicus, 109 Prochilodus lineatus, and 108 R. aspera. There were differences in distance of ascent, both among species and between release sites. Individuals of $B$. orbignyanus $(\mathrm{N}=151)$ released in downstream site exhibited a low failure rate from the beginning to the end of the ladder, resulting in overall passage success of $79 \%$ (Fig. 5a). For Prochilodus lineatus, we observed that individuals $(\mathrm{N}=196)$ released in the downstream site showed low entry rates, but had $100 \%$ of efficiency in ascending the ladder. Lower values were obtained for individuals of this species when marked and released in the fish ladder $(\mathrm{N}=109)$, where $69 \%$ of them ascended the passage (Fig. 5b). Piaractus mesopotamicus had the greatest passage success, with $94 \%$ of the individuals $(\mathrm{N}=204)$ released and entering from downstream site, and $78 \%$ of the individuals $(\mathrm{N}=100)$ released in the ladder ascending the fishway (Fig. 5c-d). For R. aspera, failure occurred throughout the ladder, with $43 \%$ of the individuals $(\mathrm{N}=206)$ released and entering from downstream

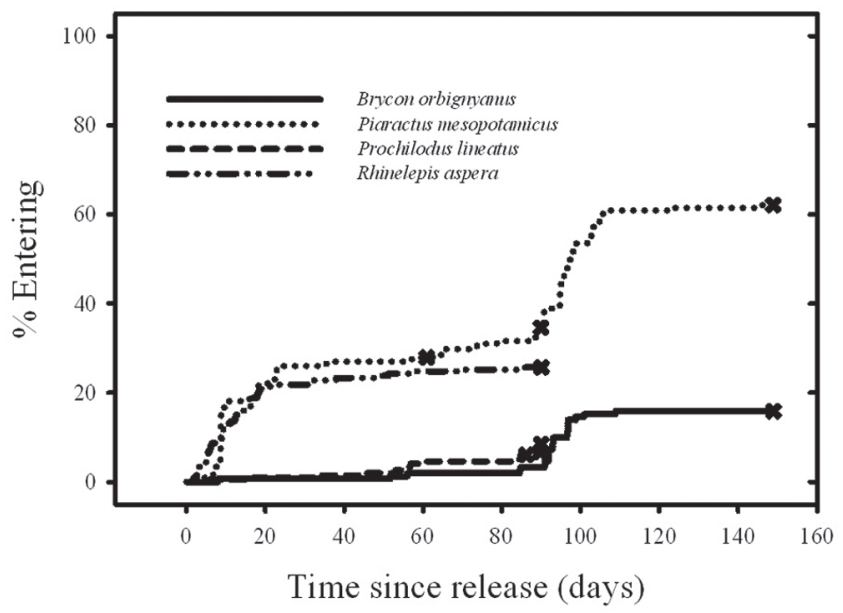

Fig. 4. Entry rates for fish released downstream that found the fish ladder entrance during study period. 
site, and $31 \%$ of the individuals $(\mathrm{N}=108)$ released in the ladder passing (Figs. 5e-f).

Movement was fastest in the lower end of the fishway (i.e., between the antennas 1-2 and 2-3), and declined as fish ascended. This may be because the lower sections required faster swimming compared with the upper sections where fish may have used the resting pools present between sections to recover from the previous effort. This can be evidenced by the failure rate at the initial section and of posterior decrease, estimated by the hazard function, for the Piaractus mesopotamicus, $R$. aspera, and Prochilodus lineatus, respectively (Fig. 6). Two extremes were observed: Prochilodus lineatus covered the whole ladder in an average transit time of $1.5 \mathrm{~h}$, and R. aspera took 178.9 hours (Fig. 6).

Handling and release location influenced rates of both passage and failure for Piaractus mesopotamicus and Prochilodus lineatus, but not $R$. aspera (Fig. 7). Piaractus mesopotamicus showed dramatic differences in passage performance and failure rate by release site. Fish released downstream had much higher success rates and lower failure rates than those released within the fishway: time to fail (LogRank, $\mathrm{p}=0.0004$; Wilcoxon, $\mathrm{p}=0.0051)$ and time to pass (LogRank, $p=0.0020$; Wilcoxon, $p=0.0295$ ). This suggests that this species was particularly sensitive to handling and might shed some light on the entry rate differences. Prochilodus lineatus had a similar pattern, but with faster passage times, which were also sensitive to release site (Log-Rank, $\mathrm{p}<0.0001$; Wilcoxon, $\mathrm{p}=0.0001$ ). For both Piaractus mesopotamicus and Prochilodus lineatus, fish released downstream that entered the fishway but failed to pass mostly failed shortly after fishway entry. Individuals that remained in the fishway longer than 2-3 h had a strong probability of success. Among Piaractus mesopotamicus movement appeared to follow a diurnal pattern, with clusters of successful passage occurring after $2 \mathrm{~h}$ and then again after $24 \mathrm{~h}$. This pattern was not apparent for Prochilodus lineatus, and it neither species exhibited this behavior when released directly into the fishway.

Those Piaractus mesopotamicus and Prochilodus lineatus that were released directly into the fishway sustained higher rates of failure throughout the duration of their attempts. Success rates were also lower for the fishway released groups of these two species. It is important here to understand that rates of success and failure should be thought of as the product of independent competing processes. For example, it is possible to have low overall passage success in the presence of low success and low failure rates - the success

\section{Brycon orbignyanus}

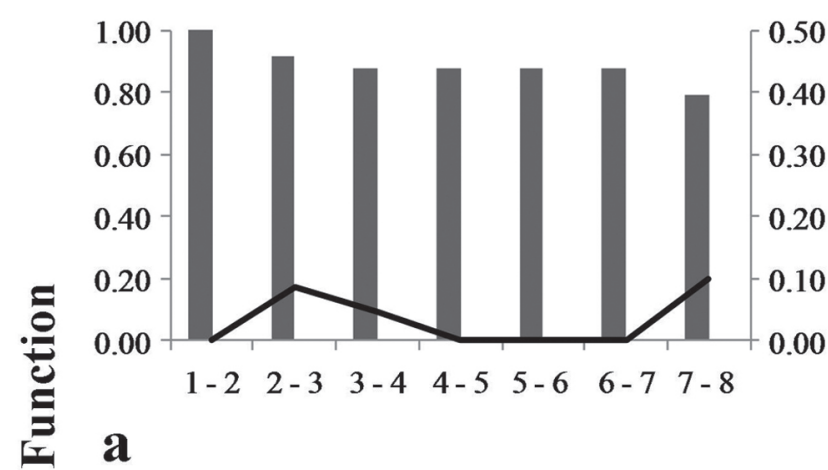

a

Rhinelepis aspera

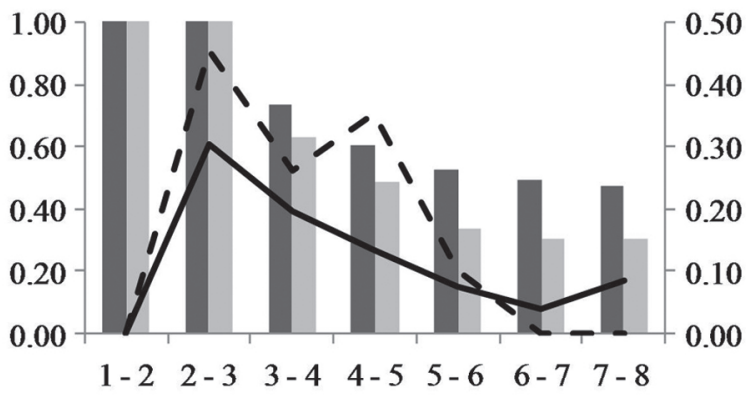

c
Prochilodus lineatus

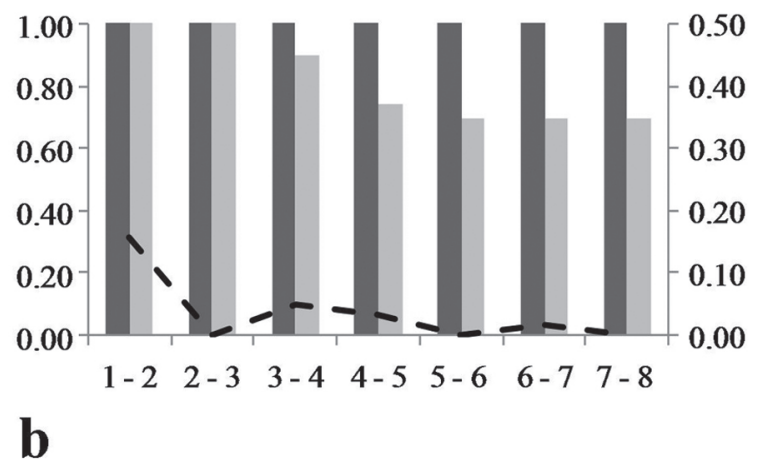

Piaractus mesopotamicus

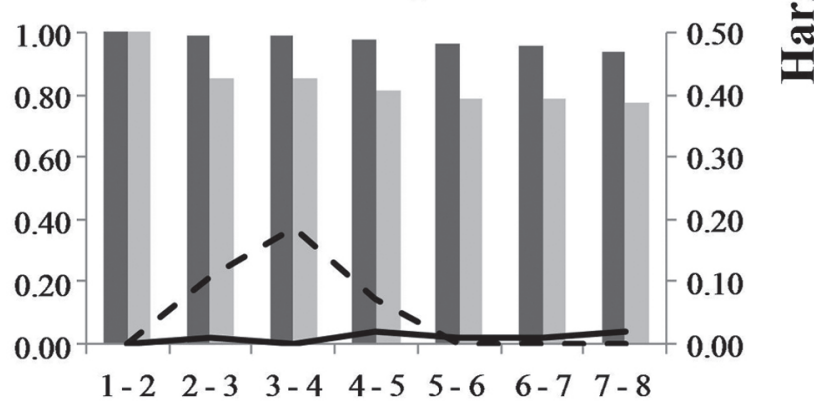

d

\section{Antennas}

Fig. 5. Ascension probabilities (bars) and failure rates (hazard function, lines) through antennas in the fish ladder for four fish species released downstream (dark gray bar; solid line) and in the fish ladder (gray bar; dashed line). 
rate only has to be greater than the failure rate for most fish to succeed. The converse is also true. By presenting the data in this way it becomes possible to characterize the process of success and failure and so understand (or at least construct hypotheses pertaining to) underlying mechanisms.
The long durations of fishway residence for $R$. aspera (Fig. 7) illustrate this point. Here, overall passage success was poor. This was partly driven by initial high failure rates, but low ascent rates and sustained high rates of rejection (failure) persisted over time, meaning that even those individuals with

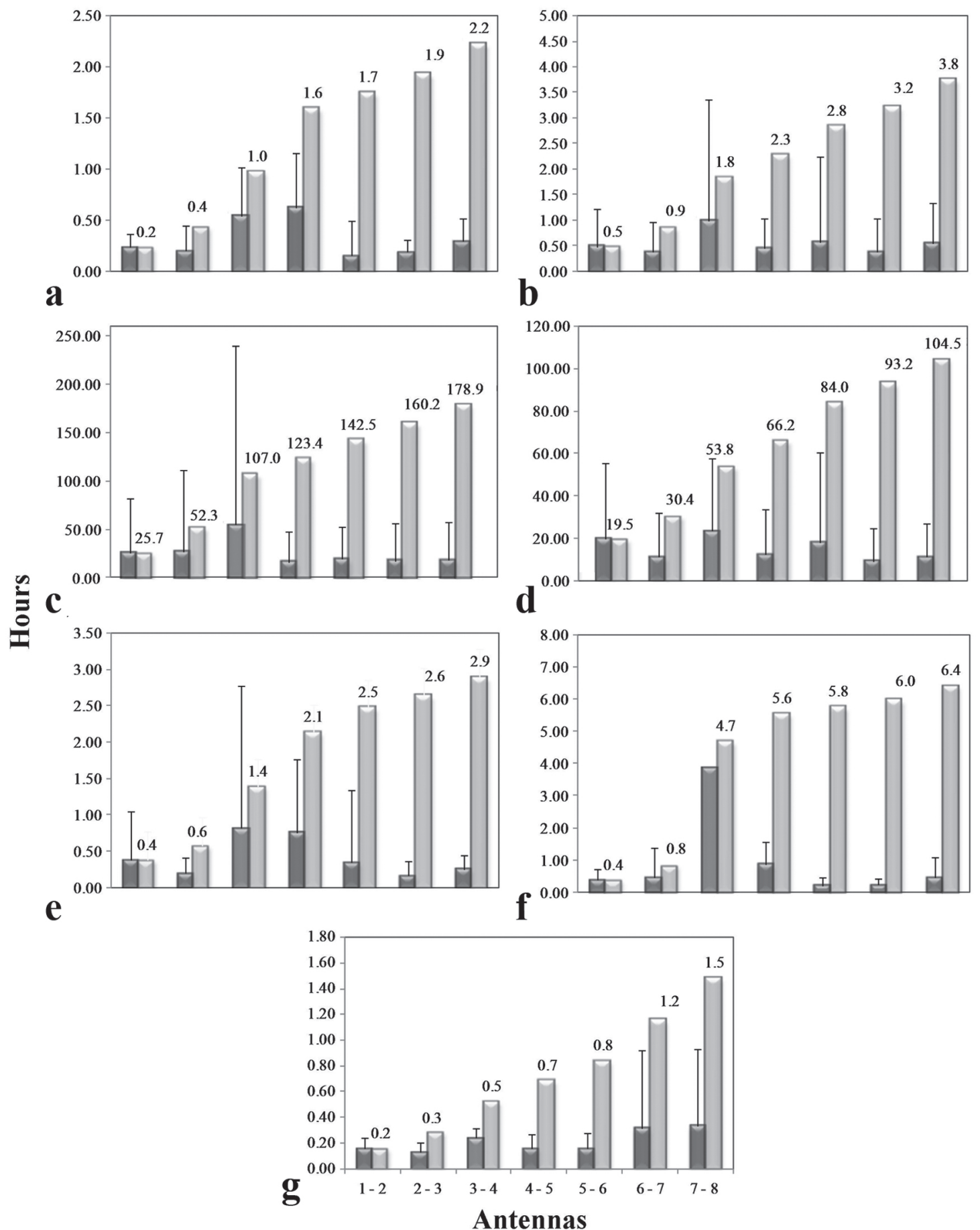

Fig. 6. Transit time between antennas (hours, dark gray bars) and cumulative transit time (hours, gray bars) for fish species released downstream and in the fish ladder. Bars represent mean \pm SD transit time of: a) Piaractus mesopotamicus (downstream), b) Piaractus mesopotamicus (fish ladder), c) Rhinelepis aspera (downstream), d) Rhinelepis aspera (fish ladder), e) Brycon orbignyanus (downstream), f) Prochilodus lineatus (fish ladder), g) Prochilodus lineatus (downstream). 
strong migratory urge that exhibited sustained effort often failed to reach the top despite their efforts.

Overall, however, this analysis shows clearly that those fish with the greatest overall passage proportions also had the fastest passage rate and had low rates of rejection (Fig. 5-7).

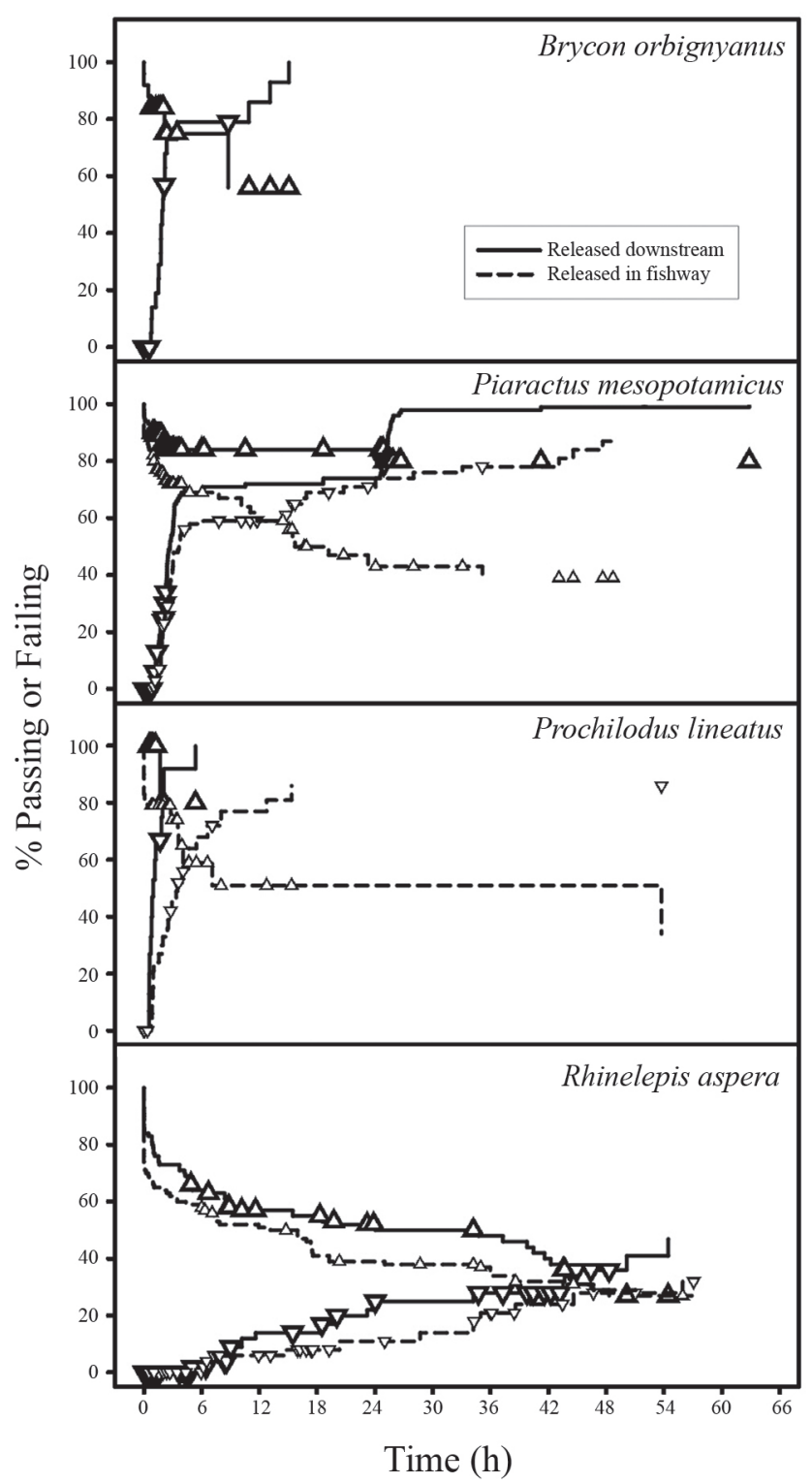

Fig. 7. Cumulative distribution functions $(F(t))$ and survivorship functions $(\mathrm{S}(\mathrm{t})$, calculated using the KaplanMeier method, (Kaplan \& Meier, 1958)) for 4 species ascending the Porto Primavera fishway, separated by release site. These functions describe the competing risks of fishway passage and fishway failure, quantified in terms of time to pass $(\mathrm{F}(\mathrm{t})$ curves, increasing functions) or fail ( $\mathrm{S}(\mathrm{t})$ curves, decreasing functions). Triangles indicate censored observations, i.e. fish that failed to pass (downward pointing) or succeeded (upward pointing). Failure connotes censoring for passage time estimates and passage connotes censoring for failure time estimates. Only the first $66 \mathrm{~h}$ of data are shown.

\section{Discussion}

In order to pass a fishway, fish must first locate and enter the structure; fishway entry is therefore just as important as passability. Despite this, only a small minority of published studies document fishway entry (Bunt et al., 2012). In this study, proportions entering the fishway differed among species, but were generally low (7.1 $55.4 \%)$. These differences among species may be associated to their behavior and biology. Rheotaxis behavior may be more pronounced for Piaractus mesopotamicus that showed higher attractiveness than other species. Mark-recapture study using external tags with this species (fish from rearing too) evidenced movements especially upstream (Makrakis et al., 2007b), and maximum rate of movement of $26 \mathrm{~km} /$ day indicating fast movement through the river. Studies carried out by Bunt et al. (1999) in Mannheim dam, Canada, estimated passage attractiveness of two fish ladders. Value of this variable was different among species (Catostomus commersoni and Micropterus dolomieu), and ranged widely, $50-82 \%$.

Estimates of ascension efficiency made in the present study showed a wide range among species (highest value for Prochilodus lineatus - $100 \%$, and the lowest for $R$. aspera-31\%). Makrakis et al. (2011) reported that in the fish passage system known as Canal da Piracema, in Itaipu Hydroelectric Power Plant, with $10 \mathrm{~km}$ of extension, only $0.5 \%$ of the migratory fish were able to reach the upstream sections of the channel and potentially the reservoir. Swimming performance of the long-distance migratory species may reflect the differences in the ascension efficiency verified among species. Santos et al. (2007) say that the swimming capacity of the piau Leporinus reinhardti explained the success of this genus in ascending fishways constructed in Brazil. The behavior at fishway and swimming capacity of Neotropical long-distance migratory species are still poorly studied, and they should be expanded to support studies on fish passages.

The most important impacts of the construction of reservoirs are on the ichthyofauna, especially on migratory fish, by intercepting their migratory routes, altering the hydrological regime, and reducing spawning and nursery habitats (Agostinho et al., 2004a; Agostinho et al., 2007a). According to Vazzoler et al. (1997), individuals of $B$. orbignyanus have their spawning peak between December and January. Ringuelet et al. (1967) reported that Piaractus mesopotamicus spawn from October to January. The spawning of Prochilodus lineatus and $R$. aspera, according to Agostinho et al. (2003) occurs from October to January. The average total time for the species to find the entrance of the fish ladder and ascend upstream of the reservoir resulted in a maximum value of 87.12 days and a minimum value of 14.35 days. The time needed for the mentioned species to carry out their migrations to spawning habitat is unknown. Migratory movement includes transposing the 
whole fish passage until arriving at the upper sections, where are favorable sites for spawning of migratory species. The species need to transpose the dam and find favorable sites in the upper section in time, without delaying their reproduction. The times observed in the present study make us question whether some of these species will be successful in finding the entrance of the ladder, ascend with relative efficiency, and find the suitable habitats for spawning.

The hazard analysis and the other analyses show that the highest difficulty for the fish is to ascend the initial section of the passage system. However, in this section the analyzed species carry out a faster movement, possibly due to the need for overcoming high velocities. In theory, the higher the elevation, the higher the flow velocity, and consequently selectivity and incapacity to transpose are also higher (Haro et al., 1999; Castro-Santos, 2005). Furthermore, efficiency is closely related to water velocity and turbulence, which must be compatible with the swimming ability of the species; failures in ascension point out the need for engineering alterations (Makrakis et al., 2011). Water velocity may be reduced by using energy dissipators (Clay, 1995; Bilgil, 2003), such as baffles or chicanes made of concrete or rocks placed in strategic sites (Makrakis et al., 2011). However, our understanding of how these interact for neotropical longdistance migratory species is poor and needs further studies. Importantly, strong currents can help stimulate fish to ascend a ladder, so reducing velocity is not always desirable - this has to be balanced with the need to provide conditions that don't cause fatigue.

The differences we observed among species in entry rates and travel times suggest that further studies in species travel time including other species are needed. The time required to enter and pass the fishway, considering the migratory period ('piracema'), should be analyzed with greater precision, testing whether long-distance migratory species are able to reach favorable reproduction sites, i.e., upstream tributaries, and are able to carry out reproduction despite delays.

Although the literature has reports of passages of anadromous fish species, there is barely any study on success or failure of individual fish or group of fish that could be used to make estimates of passage attractiveness and efficiency for Neotropical fish species. Studies on Neotropical fish species only report the percentage of species found in passage systems, in relation to the total amount of fish species recorded in the study region. Data available in the literature (Fernandez et al., 2004; Agostinho et al., 2007b; Makrakis et $a l ., 2007 \mathrm{c}$ ) show that most passage systems of South America fail in terms of species selectivity.

Passage performance through the fish ladder of Engenheiro Sérgio Motta Hydroelectric Power Plant, is not sufficient to meet standards of permeability, and it appears to be that fish had difficulty locating and entering the ladder. Passage efficiency was poor for most species, although it was good for Prochilodus lineatus. Those fish that fail to pass may have opportunity to find alternative routes downstream of the dam to complete their reproductive cycle as mentioned by Antonio et al. (2007) in studies realized before fish ladder construction. Additionally, the small proportion entering and passing the fishway could migrate into critical habitats for spawning in the tributaries upstream of Porto Primavera dam (Silva et al., 2012).

The species studied exhibited different rates of passage and failure, both among species and between release sites. The improved passage success among fish released downstream resulted from both improved passage rates and reduced failure rates. This implies that the handling and marking process might have influenced these results. Importantly, the reduction in passage rates suggests that handling effects may have sustained influence, and assumptions that fish that move upstream are unaffected (a common characteristic of telemetry studies) might not be appropriate (Liedtke \& Wargo Rub, 2012). The lack of difference between fishway and downstream releases among $R$. aspera suggests that the low performance for this species was largely caused by the fishway. The fact that so many individuals were able to remain within the fishway for many days at a time suggests that fatigue was not the driving factor, but instead points to some other structural or hydraulic characteristic of the fishway that precluded their rapid ascent.

Future studies are necessary to correlate environmental variables, such as turbine and spillway discharges, atmosphere pressure, and precipitation that could influence entry rates. Although RFID can be a very cost-effective method for monitoring passage performance, it is less effective for understanding factors affecting fishway entry. Where possible, a better approach is to employ both radio (or acoustic) and PITtelemetry. In this way it is possible to design studies and analyses that allow for varying exposure to the fishway entrance, and to differentiate between guidance or approach to the entrance and the actual entry event (Castro-Santos \& Perry, 2012). Where fishway entrances are shown to have poor effectiveness, as we have shown here, it is appropriate to advance to this next phase of study. Also, we recommend monitoring the fishway by marking and releasing target-species on both banks of the river. Video monitoring of passage counts and behaviors can also provide information on timing and possible mechanisms of failure. Finally, monitoring of the occurrence and abundance of eggs and fish larvae, as well as of juveniles, immediately below and above the dam, will be necessary to determine the availability of suitable spawning and nursery areas and recruitment. This information will be essential to assess the real role of the ladder and how it should be operated.

\section{Acknowledgments}

We thank Companhia Energética de São Paulo (CESP) and Agência Nacional de Energia Elétrica (ANEEL) for financial and logistic support, and Conselho Nacional de Desenvolvimento Científico e Tecnológico (CNPq) for Produtividade em Pesquisa-PQ (MCM) scholarship. 


\section{Literature Cited}

Agostinho, A. A., L. C. Gomes \& F. M. Pelicice. 2007a. Ecologia e Manejo de Recursos Pesqueiros em Reservatórios do Brasil. Maringá, EDUEM, 507p.

Agostinho, C. S., A. A. Agostinho, F. M. Pelicice, D. A. de Almeida \& E. E. Marques. 2007b. Selectivity of fish ladders: a bottleneck in Neotropical fish movement. Neotropical Ichthyology, 5: 205-213.

Agostinho, A. A., L. C. Gomes, H. I. Suzuki \& H. F. Júlio Jr. 2003. Migratory fishes of the Upper Paraná River Basin, Brazil. Pp. 19-98. In: Carolsfeld, J., B. Harvey, C. Ross \& A. Baer (Eds.). Migratory fishes of South America: Biology, Fisheries and Conservation Status. Victoria, Canadá, World Bank, 372p.

Agostinho, A. A., L. C. Gomes, S. Veríssimo \& E. K. Okada. 2004a. Flood regime, dam regulation and fish in the Upper Paraná River: effects on assemblage attributes, reproduction and recruitment. Reviews in Fish Biology and Fisheries, 14: 11-19.

Agostinho, A. A., L. M. Bini, L. C. Gomes, H. F. Júlio Jr., C. S. Pavanelli \& C. S. Agostinho. 2004b. Fish Assemblages. Pp. 223-246. In: Thomas S. M., A. A. Agostinho, N. S. Hahn (Eds.). The Upper Paraná River and its Floodplain physical aspects, ecology and conservation. Leinden, Netherlands, Backhuys Piblishers.

Agostinho, A. A., F. M. Pelicice \& L. C. Gomes. 2008. Dams and the fish fauna of the Neotropical region: impacts and management related to diversity and fisheries. Brazilian Journal of Biology, 68: 1119-1132.

Antonio, R. R., A. A. Agostinho, F. M. Pelicice, D. Bailly, E. K. Okada \& J. H. P. Dias. 2007. Blockage of migration routes by dam construction: can migratory fish find alternative routes? Neotropical Ichthyology, 5: 177-184.

Allison, P. D. 1995 Survival analysis using the SAS system: A Practical Guide. Cary, North Carolina, SAS Institute Inc, 292p.

Armstrong, J. D., V. A. Braitwaite \& P. Rycroft. 1996. A flat-bed passive intragrated transponder array for monitoring behaviour of Atlantic Salmon parr and other fish. Journal of Fish Biology, 48: 539-541.

Bilgil, A. 2003. Effect of wall shear stress distribution on Manning Coefficient of smooth open rectangular channel flows. Turkish Journal of Engineering \& Environmental Sciences, 27: 305-313.

Bunt, C. M., C. Katopodis \& R. S. Mckinley. 1999. Attraction and Passage Efficiency of White Suckers and Smallmouth Bass by Two Denil Fishways. North American Journal of Fisheries Management, 19: 793-803.

Bunt, C. M., T. Castro-Santos \& A. Haro. 2012. Performance of fish passage structures at upstream barriers to migration. River Research and Applications, 28: 457-478.

Castro-Santos, T. 2004. Quantifying the combined effects of attempt rate and swimming capacity on passage through velocity barriers. Canadian Journal of Fisheries and Aquatic Sciences, 61: 16021615.

Castro-Santos, T. 2005. Optimal swim speeds for traversing velocity barriers: an analysis of volitional high-speed swimming behavior of migratory fishes. Journal of Experimental Biology, 208: 421-432.

Castro-Santos, T. 2012. Adaptive fishway design: a framework and rationale for effective evaluations. Bundesanstalt für Gewässerkunde, Veranstaltungen, 7/2012: 76-89.

Castro-Santos, T. \& A. Haro. 2003. Quantifying migratory delay: a new application of survival analysis methods. Canadian Journal of Fisheries and Aquatic Sciences, 60: 986-996.

Castro-Santos, T. \& A. Haro. 2010. Fish guidance and passage at barriers. Pp 62-89. In: Domenici, P. \& B. G. Kapoor (Eds.).
Fish Locomotion: An Eco-Ethological Perspective. Science Publishers, Enfield, NH.

Castro-Santos,T. \& R.W. Perry. 2012. Time-to-event analysis as a framework for quantifying fish passage performance. Pp. 427 452. In: N. S. Adams, J. W. Beeman \& J. Eiler (Eds.). Telemetry Techniques. American Fisheries Society, Bethesda, MD.

Castro-Santos, T., A. Haro \& S. Walker. 1996. A Passive Integrated Transponder (PIT) Tag System for Monitorig Fishways. Fisheries Research, 28: 253-261.

Castro-Santos, T., A. Cotel \& P. W. Webb. 2009. Fishway evaluations for better bioengineering - an integrative approach. Pp. 557-575. In: Haro, A. J., K. L. Smith, R. A. Rulifson, C. M. Moffit, R. J. Klauda, M. J. Dadswell, R. A. Cunjak, J. E. Cooper, K. L. Beal \& T. S. Avery (Eds.). Challenges for diadromous fishes in a dynamic global environment. American Fisheries Society, Symposium 69, Bethesda, Maryland.

Clay, C. H. 1995. Design of Fishways and Other Fish Facilities. 2nd ed., Lewis Publishers: Boca Raton, Ann Arbor, London, Tokyo, 248p.

Collins, G. B. \& C. H. Elling. 1960. Fishway Research at the Fisheries-Engineering Research. Laboratory. U.S. Fish and Wildlife Service Circular 98. Washington D.C.

Godoy, M. P. 1985. Aquicultura: aquicultura-atividade multidisciplinar: escadas e outras facilidades para passagens de peixes; estações de piscicultura. Florianópolis, ELETROSUL, 77p.

Fernandez, D. R., A. A. Agostinho \& L. M. Bini. 2004. Selection of an experimental fish ladder located at the dam of the Itaipu Binacional, Paraná River, Brazil. Brazilian Archives of Biology and Technology, 47: 579-586.

Greenberg, A. \& P. S. Giller. 2000. The potential of flat-bed passive integrated transponder antennae for studying habitat use by stream fishes. Ecology of Freshwater Fish, 9: 74-80.

Haro, A., M. Odeh, T. Castro-Santos \& J. Noreika. 1999. Effect of slope and headpond on passage of American shad and blueback herring through simple Denil and deepened Alaska steeppass fishways. North American Journal of Fisheries Management, 19: $51-58$

Haro, A., T. Castro-Santos, J. Noreika \& M. Odeh. 2004. Swimming performance of upstream migrant fishes in openchannel flow: a new approach to predicting passage through velocity barriers. Canadian Journal of Fisheries and Aquatic Sciences, 61: 1590-1601.

Kaplan, E. \& P. Meier. 1958. Nonparametric estimation from incomplete observations. Journal of the American Statistical Association, 53: 457-481.

Larinier, M. 2001. Environmental issues, dams and fish migration. Pp. 45-89. In: Marmulla, G. (Ed.). Dams, Fish and Fisheries: Opportunities, Challenges and Conflict Resolution. FAO Fisheries Technical Paper. Rome, 419p.

Larinier, M. 2002. Fishways: general considerations. Pp. 21-27. In: Larinier, M., F. Travade \& J. P. Porcher (Eds.). Fishways: Biological Basis, Design Criteria and Monitoring. Bulletin Français de la Pêche et de la Pisciculture. Conseil Supérieur de la Pêche. Paris, 364p.

Liedtke,T. L. \& A. M. Wargo Rub. 2012. Techniques for telemetry transmitter attachment and evaluation of transmitter effects on fish performance. Pp. 45-87. In: N. S. Adams, J. W. Beeman \& J. H. Eiler (Eds.). Telemetry techniques: a user guide for fisheries research. American Fisheries Society, Bethesda, MD, USA.

Makrakis, S. 2007. O Canal da Piracema como sistema de transposição de peixes. Unpublished Ph.D Thesis, Universidade Estadual de Maringá, Maringá. 60p. 
Makrakis, S., L. C. Gomes, M. C. Makrakis, R. L. Wagner \& J. H. P. Dias. 2007a. Utilization of the fish ladder at the Engenheiro Sérgio Motta Dam, Brazil, by long distance migrating potamodromous species. Neotropical Ichthyology, 5: 197-204.

Makrakis, M. C., L. E. Miranda, S. Makrakis, A. M. M. Xavier, H. M. Fontes-Júnior \& W. G. Morlis. 2007b. Migratory movements of pacu, Piaractus mesopotamicus, in the highly impounded river. Journal of Applied Ichthyology, 1: 1-18.

Makrakis, S., L. C. Gomes, M. C. Makrakis, D. R. Fernandez \& C. S. Pavanelli. 2007c. The Canal da Piracema as a fishpass system. Neotropical Ichthyology, 5: 185-195.

Makrakis, S., L. E. Miranda, L. C. Gomes, M. C. Makrakis \& H. M. F. Junior. 2011. Ascent of Neotropical Migratory Fish in the Itaipu Reservoir Fish Pass. River Research and Applications, 27: 511-519.

Pelicice, F. M. \& A. A. Agostinho. 2008. Fish - Passage Facilities as Ecological Traps in Large Neotropical Rivers. Conservation biology, 22: 180-188.

Pompeu, P., A. A. Agostinho \& F. M. Pelicice. 2012. Existing and future challenges: the concept of successful fish passage in South America. River Research and Applications, 28: 504-512.

Prentice, E. F., T. A. Flaag \& S. Mccutcheon. 1990. Feasibility of using implanted passive integrated transponder (PIT) tags en salmonids. American Fisheries Society Symposium, 7: 317-322.

Prosser, N. S. 1986. An overview of reservoir fisheries problems and opportunities resulting from hydropower. Pp. 238-246. In: Hall G. E. \& M. J. Van Den Avyle (Eds.). Reservoir fisheries management: strategies for 80 's. Reservoir Committee, Southern Division American Fisheries Society. Bethesda, Maryland.

Quirós, R. 1988. Structures assisting migrations of fish other than salmonids: Latin America. FAO-COPESCAL Technical Document, Rome, 5: 1-50.

Ringuelet, R. A., R. H. Aramburu \& A. A. Aramburu. 1967. Los peces argentinos de agua dulce. Comisión de Investigaciones Científicas. La Plata, 602p.
Santos, H. A., P. S. Pompeu \& C. B. Martinez. 2007. Swimming performance of the migratory Neotropical fish Leporinus reinhardti (Characiformes: Anostomidae). Neotropical Ichthyology, 5: 139-146.

SAS Documentation. 2010. The Lifetest Procedure. Pp. 3098-30183. In: SAS/Stat 9.2 User's Guide the Lifetest procedure (Book Excerpt). Cary, North Carolina, SAS Institute Inc.

Silva, P. S., M. C. Makrakis, S. Makrakis, A. F. Lima, L. Assumpção, S. Paula, L. E. Miranda, J. H. P. Dias. 2012. Spawning and nursery habitats of neotropical fish species in the tributaries of a regulated river. Pp. 153-166. In: K. Pourali \& V. N. Raad (Eds.). Larvae: Morphology, Biology and Life Cycle. New York, Nova Science Publishers, 208p.

Sullivan, T. J. 2004. Evaluation of the Turners Falls fishway complex and potential improvements for passing adult American shad. Unpublished Ph.D Dissertation, University of Massachusetts Amherst. 105p.

Thiem, J. D., T. R. Binder, J. W. Dawson, P. Dumont, D. Hatin, C. Katopodis, D. Z. Zhu, S. J. Cooke. 2011. Behaviour and passage success of upriver-migrating lake sturgeon Acipenser fulvescens in a vertical slot fishway on the Richelieu River, Quebec, Canada. Endangered Species Research, 15: 1-11.

Vazzoler, A. E. A. de M., H. I. Suzuki, E. E. Marques \& M. de Los A. P. Lizama. 1997. Primeira maturação gonadal, períodos e áreas de reprodução. Pp. 249-265. In: Vazzoler, A. E. A. de M., A. A. Agostinho, N. S. Hahn (Eds.). A planície de inundação do alto rio Paraná: aspectos físicos, biológicos e socioeconômicos. Maringá, EDUEM, 460 p.

Zydlewski, G. B., A. Haro, K. G. Whalen \& S. D. McCormick. 2001. Performance of stationary and portable passive transponder detection systems for monitoring of fish movements. Journal of Fish Biology, 58: 1471-1475.

Submitted March 21, 2012 Accepted October 15, 2012 